\title{
Growth and carbon assimilation limitations in Ricinus communis (Euphorbiaceae) under soil water stress conditions
}

\author{
Tanise Luisa Sausen ${ }^{1}$ and Luís Mauro Gonçalves Rosa ${ }^{2,3}$
}

Recebido em 28/04/2009. Aceito em 5/02/2010

\begin{abstract}
RESUMO - (Crescimento e limitações à assimilação de carbono em Ricinus communis (Euphorbiaceae) sob condições de estresse hídrico do solo). A disponibilidade hídrica pode influenciar o ganho de carbono e o crescimento, com grande impacto na produtividade das plantas. Ricinus communis (L.), uma espécie resistente à seca, é uma cultura de grande importância econômica no Brasil, devido ao seu uso na indústria química e para a produção de biocombustíveis. Alguns dos mecanismos envolvidos na resistência à seca desta espécie foram analisados através de um progressivo estresse hídrico em plantas cultivadas em vasos sob condições de casa de vegetação. A suspensão da irrigação por 53 dias decresceu o conteúdo gravimétrico de água no solo e o potencial hídrico das folhas. O crescimento das plantas foi negativamente e significativamente reduzido pelo aumento do déficit hídrico do solo. Com a suspensão da irrigação, a assimilação de carbono e a transpiração foram reduzidas e permaneceram praticamente constantes ao longo do dia. A análise das curvas $\mathrm{A} / \mathrm{C}_{\mathrm{i}}$ demonstrou o aumento da limitação estomática, indicando que a limitação imposta pelo fechamento dos estômatos é o principal responsável pela redução da fotossíntese. A eficiência de carboxilação e a taxa de transporte de elétrons não foram afetadas pelo estresse hídrico até 15 dias de suspensão da irrigação. A resistência à seca da mamona parece estar relacionada a uma resposta inicial e pronunciada do crescimento, a um eficiente controle estomático e a capacidade de manter uma alta taxa de fixação de $\mathrm{CO}_{2}$ sob condições de estresse hídrico.
\end{abstract}

Palavras-chave: curvas $\mathrm{A} / \mathrm{Ci}$, estresse hídrico, fotossíntese, limitação estomática, padrão diário

ABSTRACT - (Growth and limitations to carbon assimilation in Ricinus communis (Euphorbiaceae) under soil water stress conditions). Water availability may influence plant carbon gain and growth, with large impacts on plant yield. Ricinus communis (L.), a drought resistant species, is a crop with increasing economic importance in Brazil, due to its use in chemical industry and for the production of biofuels. Some of the mechanisms involved in this drought resistance were analyzed in this study by imposing progressive water stress to pot-grown plants under glasshouse conditions. Water withholding for 53 days decreased soil water gravimetric content and the leaf water potential. Plant growth was negatively and significantly reduced by increasing soil water deficits. With irrigation suspension, carbon assimilation and transpiration were reduced and remained mostly constant throughout the day. Analysis of A/ $\mathrm{C}_{\mathrm{i}}$ curves showed increased stomatal limitation, indicating that limitation imposed by stomatal closure is the main factor responsible for photosynthesis reduction. Carboxylation efficiency and electron transport rate were not affected by water stress up to 15 days after withholding water. Drought resistance of castor bean seems to be related to a pronounced, early growth response, an efficient stomatal control and the capacity to keep high net $\mathrm{CO}_{2}$ fixation rates under water stress conditions.

Key words: A/Ci curves, diurnal changes, photosynthesis, stomatal limitations, water stress

\section{Introduction}

Drought is the major factor limiting crop productivity worldwide (Jones \& Corlett 1992), and crops with increased resistance to this stress appear to be crucial for maintaining yields in areas where dry seasons are common. Ricinus communis (L.), also known as castor bean, is a crop with increasing economic importance in Brazil, due to its use in pharmaceutical and chemical industry and, mainly, as a substitute for diesel in the production of biofuels. Castor bean is considered a drought resistant species, and, for this reason, it has been grown mostly in arid zones in Brazil. However, little is known about the physiological mechanisms underlying its resistance to drought. Dai et al. (1992) observed that, under increased vapor pressure deficits, the inhibitory effect of drought upon photosynthesis in castor bean plants is caused by limited leaf $\mathrm{CO}_{2}$ concentration, due to stomatal closure. Castor bean is a species in which stomata remain partially open at night and it was observed that drought reduced stomatal conductance over the day and also at night (Barbour \& Buckley 2007).

Despite significant advances in the understanding of mechanisms by which photosynthesis responds to environmental factors, there is still controversy about the actual importance of diffusional and metabolic limitations to photosynthesis imposed by drought. Generally, the initial decrease of photosynthesis is due to stomatal closure, which protects the plant against excessive water loss, but simultaneously limits $\mathrm{CO}_{2}$ availability to the leaf mesophyll (Chaves 1991; Flexas et al. 2002; Flexas \& Medrano 2002). Besides stomatal limitations, metabolic limitations to photosynthesis, related to reduced RuBP regeneration (Gimenez et al. 1992; Gunasekera \& Berkowitz 1993), Rubisco activity (Medrano et al. 1997), ATP production (Tezara et al. 1999; Lawlor \& Cornic 2002), photosystem II (PSII) activity and electron transport rate (Long et al. 1994) have also been proposed. The extension of stomatal and metabolic limitations imposed by water stress on photosynthesis will affect diurnal patterns of gas exchange. An efficient regulation of photosynthesis throughout the day reflects plant capacity to maintain an internal balance among several processes as it responds to varying environmental conditions (Geiger \& Servaites 1994). The general objective of this study is to better understand the mechanisms used by castor bean to tolerate drought. More specifically this paper aims to study the effects of soil water-deficits on plant growth and biomass allocation and on the daily

\footnotetext{
Universidade Federal do Rio Grande do Sul, Instituto de Biociências, Laboratório de Ecofisiologia Vegetal, Porto Alegre, RS, Brasil

2 Universidade Federal do Rio Grande do Sul, Faculdade de Agronomia, Laboratório de Ecofisiologia Vegetal, Porto Alegre, RS, Brasil

Corresponding Author: 1mrosa@ufrgs.br
} 
pattern of gas exchange in castor bean plants, quantifying and comparing the diffusional and metabolic limitations to the photosynthetic process under limited water availability.

\section{Material and methods}

Plant material and growth conditions - Seeds of Ricinus communis (L.), cultivar BRS 149 Nordestina, were germinated on a mixture of commercial growth medium $\left(\right.$ TerraPreta $\left.{ }^{\mathbb{E}}\right)$ and sand $(2: 1, \mathrm{v}: \mathrm{v})$ in plastic cups (150 $\mathrm{mL})$, under constant temperature $\left(25 \pm 2{ }^{\circ} \mathrm{C}\right)$ and 12 hour light/dark period provided by a germination chamber (BOD-NT708). Upon opening of the cotyledonary leaves, seedlings were transferred to $3 \mathrm{~L}$ plastic pots $(1$ plant per pot) filled with the same growth medium and acclimated for 53 days, so that all plants would have, at least, 3 fully developed leaves, under natural environmental conditions, in a glasshouse at the School of Agronomy of the Federal University of Rio Grande do Sul, Brazil. Temperature and humidity inside the glasshouse recorded on a data logger (Pinguim, Novus Automation) installed at plant height, revealed temperature varying between 20 and $40^{\circ} \mathrm{C}$ and relative humidity between 24 and $80 \%$ during the growth period.

After the acclimation period, plants were assigned to one of two treatments, on a completely randomized design: well-watered (control) and water-stressed plants. Twenty and twenty-seven experimental units (plants) were assigned to the control and water stress treatments, respectively. The control plants continued to receive daily irrigation, with enough water to maintain soil water content at $\cong 70 \%$ of field capacity. Water stress was imposed by withholding irrigation. The reduction of the soil water content on the water stress treatment was gravimetrically monitored on a daily basis, by recording pot weight. In order to reduce soil water loss through evaporation, pots were covered with expanded polyethylene. Measurements started five days after imposing the treatments. The whole experiment (including the acclimation period) was run from August 23 to November 162006.

Water status - Plant water status was evaluated every 15 days by measurements of pre-dawn leaf water potential $\left(\psi_{\text {wed }}\right)$, using a pressure chamber (3005 model, Soilmoisture Equipment Co., EUA). Water potential was measured on leaves which were right below those used for gas exchange measurements.

Gas exchange measurements - The daily gas exchange pattern was evaluated every 15 days (with a total of 4 evaluations) by measuring carbon assimilation (A) and transpiration rate (E) in 10 plants from each treatment, every two hours, from 8:00 am to $6: 00 \mathrm{pm}$, using a portable infrared gas analyzer (Licor 6400; LiCor Inc., Lincoln, NE, USA). The youngest fully expanded leaves of the main branch of each plant were used for these measurements. Photosynthetically active radiation (PAR) inside the leaf chamber was fixed in $1500 \mu \mathrm{mol} \mathrm{m}^{-2} \mathrm{~s}^{-1}$. The $\mathrm{CO}_{2}$ concentration inside the chamber was controlled using $\mathrm{CO}_{2}$ bottles and fixed on $400 \mathrm{ppm}$. Temperature and relative humidity fluctuated naturally, according to the environmental conditions inside the glasshouse. In order to analyze the diurnal variations of gas exchange, all four evaluations taken on control plants were grouped together and measurements were averaged for each time of the day. In the water-stressed plants, two groups were established according to the time elapsed from the moment of water withholding. The first group includes measurements taken up to 15 days after withholding water (water stressed, WS). The second group includes measurements taken from 30 days after withholding water up to the last day of measurements (progressive water stress, progressive WS).

The $\mathrm{CO}_{2}$ response curves of photosynthesis $\left(\mathrm{A}-\mathrm{C}_{i}\right)$ were analyzed at the $14^{\text {th }}$ day after irrigation suspension (leaf water potential between $-1.0 \mathrm{MPa}$ and $-1.5 \mathrm{MPa}$ ). The $\mathrm{A}-\mathrm{C}_{i}$ curves were made in the laboratory, in four plants from each treatment (control and water stressed). Chamber temperature was kept between $25^{\circ}$ and $26^{\circ} \mathrm{C}$. Photosynthetic active radiation was $1500 \mu \mathrm{mol} \mathrm{m}^{-2} \mathrm{~s}^{-1}$, and relative humidity between 50 and $60 \%$. The A- $\mathrm{C}_{i}$ curves were obtained with short shot measurements (approximately 2 minutes in each point), starting with a $\mathrm{CO}_{2}$ concentration of $400 \mu \mathrm{mol}$ $\mathrm{mol}^{-1}$ and progressively reducing it to $50 \mu \mathrm{mol} \mathrm{mol}^{-1}$. At this point, $\mathrm{CO}_{2}$ concentration was progressively raised until $800 \mathrm{\mu mol} \mathrm{mol}^{-1}$. The following parameters were then calculated, according to the mathematical model for carbon assimilation proposed by von Caemmerer \& Farquhar (1981): $\mathrm{V}_{\text {cmax }}$ (maximum carboxylation rate), $\mathrm{J}_{\max }$ (maximum electron transport rate), $\mathrm{A}_{\max }$ (maximum carbon assimilation rate upon light and $\mathrm{CO}_{2}$ saturation conditions). Stomatal limitation (L ) was also calculated, according to the model of Farquhar \& Sharkey (1982). Another curve was performed on the $40^{\text {th }}$ day after water withholding, when plants reached pre-dawn leaf water potentials between $-1.6 \mathrm{MPa}$ and $-2.1 \mathrm{MPa}$. However, due to the pronounced stomatal closure of these plants, the response curves were not meaningful and are not presented.

Growth parameters - Shoot growth rate was weekly evaluated from the $53^{\text {rd }}$ day after plant emergence, by measuring shoot length from the base to the top of the stem, with a graduated ruler. At the end of the experiment, the shoot was separated from the root system for dry mass $\left(60{ }^{\circ} \mathrm{C}\right.$ until constant dry weight) measurements. Leaf area was evaluated with a leaf area meter (LiCOR 3100). Based on mass and area measurements, the following parameters were calculated: root:shoot mass ratio, leaf mass per area (LMA) and leaf area ratio (LAR).

Chlorophyll concentration - At the end of the experiment, five leaf disks $(0.5$ $\mathrm{cm}$ diameter) from the youngest fully expanded leaf of each experimental unit were collected to determine leaf chlorophyll concentration. Chlorophyll was extracted using $100 \%$ ethanol. Absorbance readings were taken at wavelengths of 649 and $665 \mathrm{~nm}$, using a spectrophotometer (Beckman DU 65, Fullerton, CA). Chlorophyll concentration was estimated using the equations of Wintermann \& De Mots (1965).

Statistical analyses - Data were subjected to one-way analysis of variance (ANOVA). All pairwise comparisons of individual means were made with Tukey $t$-test. Differences were considered significant at $P \leq 0.05$. All tests were performed using SigmaStat 2.03 (Systat Software Inc., Richmond, CA USA).

\section{Results and discussion}

Gas exchange and plant water deficits - Irrigation suspension resulted in reduction of gravimetric soil water content $\left(\theta_{\mathrm{m}}\right)$ from 0.30 to $0.18 \mathrm{~g} \cdot \mathrm{g}^{-1}$. Pre-dawn values of leaf water potential $\left(\Psi_{\mathrm{wPD}}\right)$ recorded at the beginning of each day of measurement varied between -0.7 and $-0.9 \mathrm{MPa}$ in wellwatered plants (WW) and showed a progressive reduction to $-2.1 \mathrm{MPa}$ in water-stressed plants (WS) (Fig. 1A and B). Maximum photosynthetic and transpiration rates reached each day were significantly reduced by water stress throughout the experiment (Fig. 1C and D). At the end, photosynthesis and transpiration had reduced by 59 and 96 $\%$, respectively. The fact that transpiration was more greatly reduced than photosynthesis on stressed plants indicates an optimization on carbon gain versus water loss (Daí et al. 1992; Schurr et al. 2000).

Diurnal variations in photosynthesis and transpiration - Well-watered plants displayed increased photosynthetic (A) and transpiration (E) rates along the day, reaching maximum values at 3:00 pm (34 and $13.4 \mu \mathrm{mol} \mathrm{m}^{-2} \mathrm{~s}^{-1}$, for A and $\mathrm{E}$, respectively), followed by a progressive decline later in the day (Fig. 2A). Plants under water stress had $45 \%$ and $59 \%$ average reduction in carbon assimilation along the day, respectively, when compared to control plants. Also, their rates of photosynthesis remained mostly constant along the day, with maximum values of $19 \mu \mathrm{mol} \mathrm{m}^{-2} \mathrm{~s}^{-1}$ on plants under WS and $14 \mu \mathrm{mol} \mathrm{m}^{-2} \mathrm{~s}^{-1}$ under progressive WS. Transpiration rates in plants under WS and progressive WS showed diurnal patterns which were similar to A, but plants under severe water stress had transpiration values close to zero (Fig. 2B). 

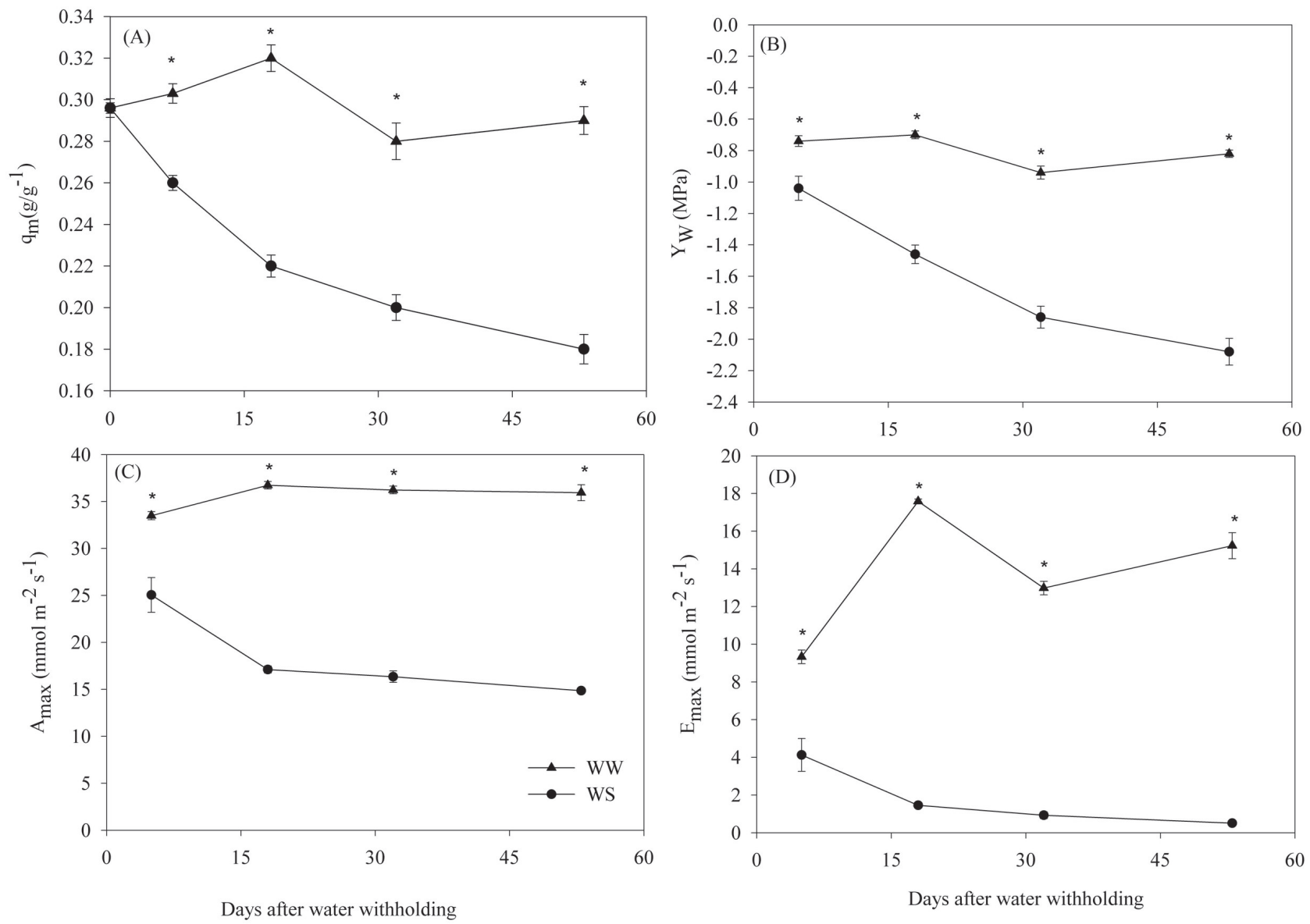

Figure 1. Effect of water withholding on (A) soil water content, $(B)$ leaf water potential $\left(\Psi_{w}\right),(C)$ maximum photosynthetic and $(D)$ maximum transpiration rate. Each point is the mean of ten measurements. Vertical bars indicate the standard deviation of the mean. Asterisks indicate difference at $P \leq 0.05$. WW= well-watered; WS= water-stressed.

Under well-watered conditions, leaf transpiration and carbon assimilation were high during most of the day. According to Dai et al. (1992), the very high photosynthetic rates exhibited by the well-watered plants can be explained by their high area-based concentration of soluble proteins, chlorophylls and Rubisco. However, under water stress conditions, castor bean showed a strong stomatal regulation of gas exchange, associated with reductions in transpiration and $\mathrm{CO}_{2}$ assimilation. Nevertheless, even with reductions between $30 \%$ (WS) to $50 \%$ (progressive WS), photosynthesis values were still high. The maintenance of the high values of photosynthesis along the day was also observed in water-stressed plants of Carica papaya (L.) by Marler \& Mickelbart (1998), and seems to be associated with the vigorous growth habitat of this species. However previous works had shown that daily gas exchange pattern of water stressed plants usually depends on the time of day (Romero \& Botía 2006; Osório et al. 2006). This pattern was not observed in this study, since the rates of $\mathrm{A}$ and $\mathrm{E}$ showed little variation along the day on the water stressed plants. This behavior might be the result of strong stomatal regulation on castor bean plants, caused by the reduction of soil water potential. The maintenance of constant values of gas exchange, on the water stressed plants, all day long may be an important characteristic of castor bean plants, as reported in previous studies (Daí et al. 1992, Schurr et al. 2000), and it may help explain the vigorous growth of the species commonly observed under high-light conditions.

Stomatal limitations of photosynthesis under water deficit - The validity of the internal $\mathrm{CO}_{2}$ concentration $\left(\mathrm{C}_{\mathrm{i}}\right)$ calculated from $\mathrm{A} / \mathrm{Ci}$ curves has been questioned (Lawlor $\&$ Cornic 2002) because of: the possibility of heterogeneous stomatal closure and increase of cuticular transpiration under conditions of water stress (Boyer et al. 1997; Buckley et al. 1997). Besides, performing these curves can become extremely difficult when low photosynthesis values are observed due to reduced levels of stomatal conductance under high $\mathrm{CO}_{2}$ concentrations (Lawlor 2002). In this study, uniform stomatal closure in castor bean in response to water deficit was assumed when analysing the stomatal $v s$. biochemical limitations to photosynthesis.

The $\mathrm{A} / \mathrm{C}_{\mathrm{i}}$ curves obtained for control and water-stressed plants (14 days after water withholding, leaf water potential between $-1.0 \mathrm{MPa}$ to $-1.5 \mathrm{MPa}$ ) were different (Fig. 3). In 

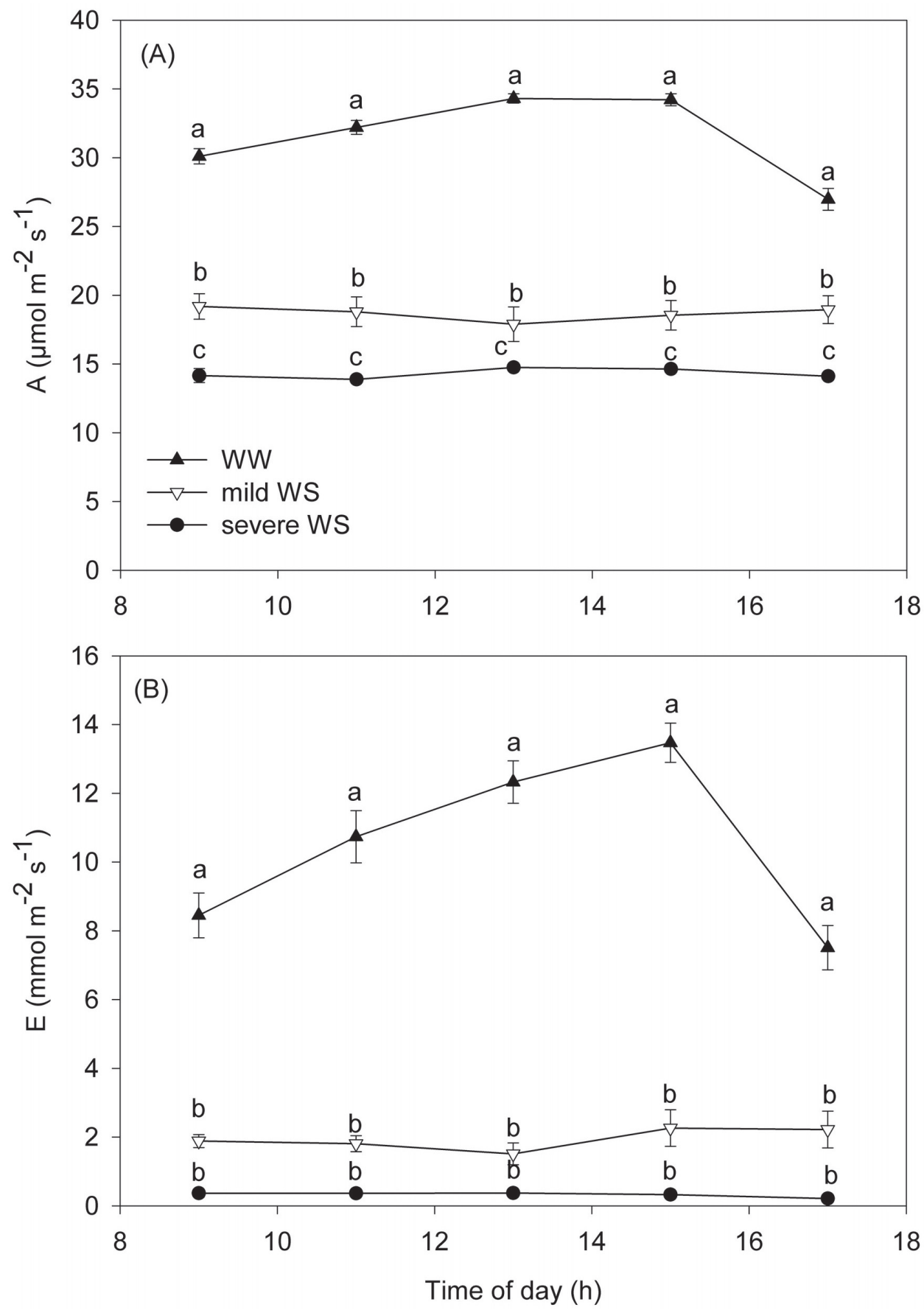

Figure 2. Diurnal courses of photosynthetic (A) and transpiration (B) rates of castor bean leaves. Well-watered plants $(\psi=-0,6$ a $-0,9 \mathrm{MPa})$, water stress plants $\left(\psi_{w}=-1,0 \mathrm{MPa}\right.$ a $\left.-1,5 \mathrm{MPa}\right)$ and progressive water stress plants $\left(\psi_{w}=-1,6 \mathrm{MPa}\right.$ a $\left.-2,1 \mathrm{MPa}\right)$. Vertical bars indicate the standard deviation of the mean. Mean values followed by same letters are not different at $P \leq 0.05$ using the Tukey test.

the stressed plants, Rubisco saturation was not observed. The analysis of biochemical parameters derived from these curves shows that the limitation imposed by stomatal closure (Fig. 4) was higher under drought (0.49) than under wellwatered (0.17) conditions. The parameters $\mathrm{V}_{\text {cmax }} \mathrm{J}_{\max }$ e $\mathrm{A}_{\max }$ did not differ between stressed and control plants.

These results indicate that reduction of photosynthesis on WS plants was caused by the increase on $\mathrm{CO}_{2}$ diffusion resistance, because of stomatal closure, and that Rubisco activity, carboxylation efficiency and electron transport rate are not affected. Similar results have been observed in previous studies (Chaves 1991; Gimen_ez et al. 1992; Tezara et al. 1999). This suggests that biochemistry of photosynthesis is preserved on WS plants and that the photosynthetic limitations observed, under these conditions, are mostly due to diffusive resistance. 


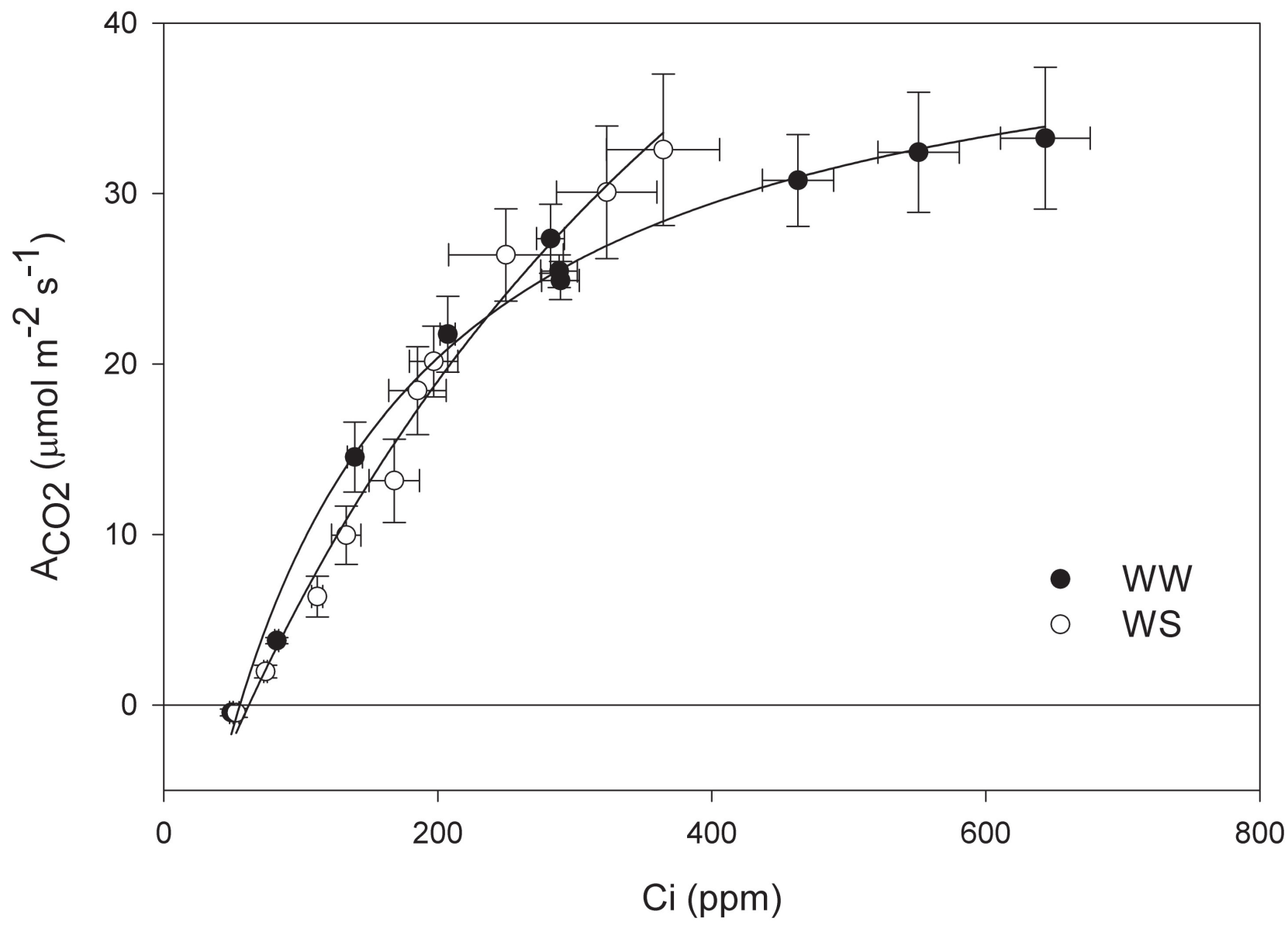

Figure 3. Mean values of net $\mathrm{CO}_{2}$ assimilation rate in control (black symbols) and water stressed (white symbols) plants of castor bean at different internal $\mathrm{CO}_{2}$ concentrations. Each value is the mean of four (control and drought) measurements \pm 2 S.D. WW= black symbols and WS white symbols.

Growth and chlorophyll responses to water deficit - As expected, at the end of the drought period, the water-stressed plants had reached predawn values of water potential below -2.0 $\mathrm{MPa}$, indicating severe reduction in water availability to their roots. Plant growth was negatively and significantly affected by this severe water deficit, expressed by reduction in shoot length, root and shoot biomasses and total leaf area (Tab. 1).

Shoot elongation was affected very early after irrigation was suspended, indicating great sensitivity of shoot growth to incipient reduction in water availability. This early growth response and the pronounced cumulative growth reduction may have contributed to plant survival after 53 days of irrigation suspension. The very small size attained by the water-stressed plants reduced plant demand for water enhancing chances of survival. Growth reduction is regarded as a characteristic associated to water stress resistance (Lecoeur et al. 1995). An early response at shoot growth to reduced water availability is related to a hormonal signaling (ABA) coming from roots (Qaderi et al. 2006). Interestingly, water deficit did not result in increased mass allocation between root and shoot and in reduced leaf area ratio (Table 1), as reported by many other studies (Poorter \& Nagel 2000; Anya \& Herzog 2004). Also, no reduction in LAR was observed. It is possible that within- organ allocation patterns (eg., lateral $v s$. tip root), not evaluated in this study, might have responded to imposed drought.

Leaf chlorophyll concentration expressed on an area basis was significantly reduced under drought conditions (Tab. 1). Although many species increase LMA when under drought stress, such increases are more commonly associated to nutrient stress (Aerts \& Chapin 2000). Considering the major reductions in leaf area and the restriction to water loss imposed by stomatal closure, it is very likely that the reduction in LMA exhibited by castor bean plants affects the leaf allocation pattern that priorizes leaf expansion at the express thickening in order to add not an extra limitation to photosynthesis.

Castor bean plants resisted water stress by avoidance mechanisms, based on early stomatal closure, thus minimizing water loss by transpiration and demand for soil water. The results also indicate that castor bean plants combine an efficient stomatal control with high levels of net $\mathrm{CO}_{2}$ fixation. Field experiments should be conducted in order to validate the results obtained in this glasshouse study. It should be noted that if castor bean plants also exhibit such avoidance responses under natural conditions, its vigorous growth will only be expressed when soil water availability is maintained at adequate levels. 

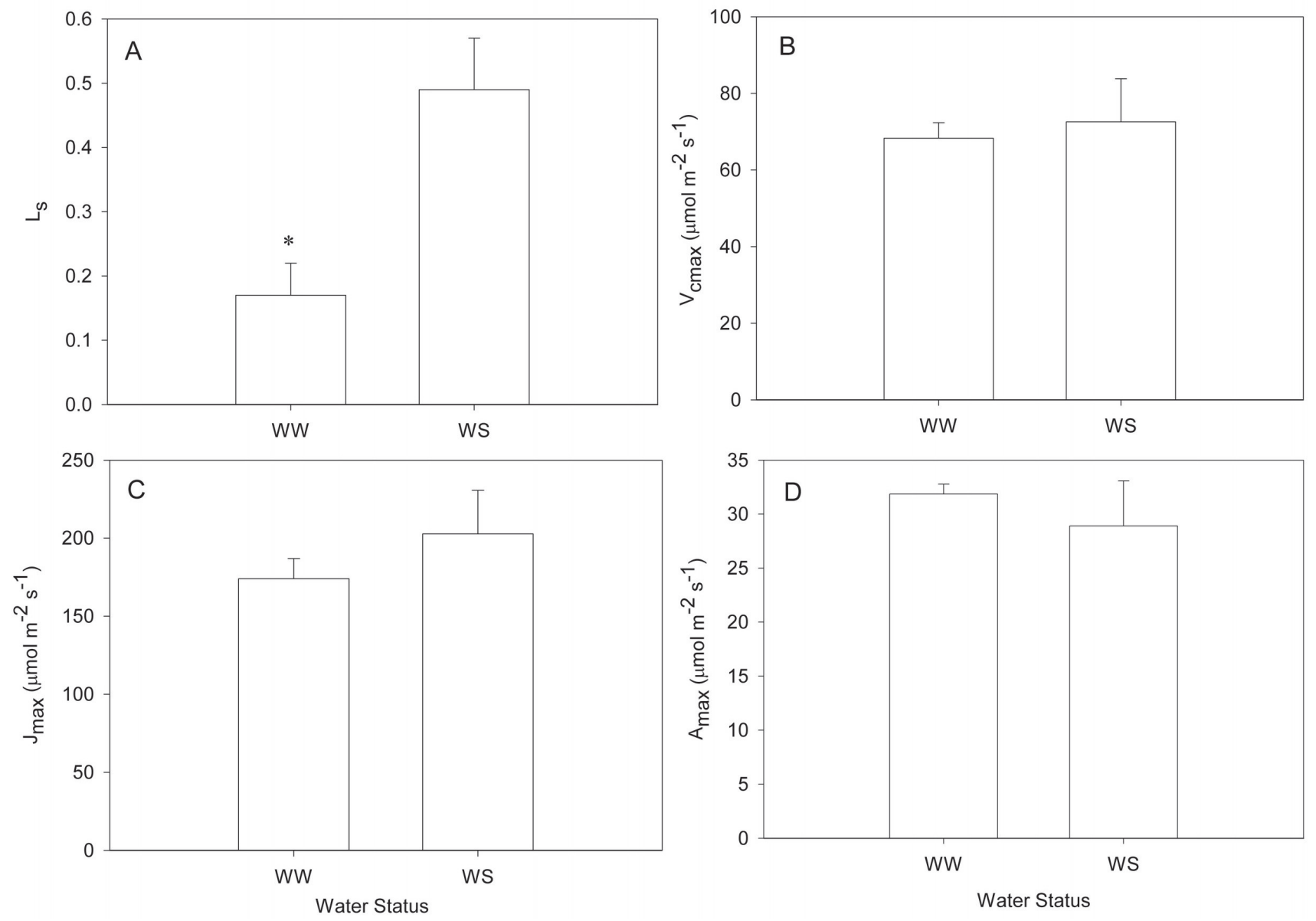

Figure 4. Effects of withholding water on $(\mathrm{A})$ stomatal limitation to photosynthesis $\left(\mathrm{L}_{\mathrm{s}}\right)(\mathrm{B})$ maximum carboxylation rate $\left(\mathrm{V}_{\mathrm{cmax}}\right)(\mathrm{C})$ electron transport driving regeneration of $\operatorname{RuBP}\left(\mathrm{J}_{\max }\right)$ and (D) maximum carbon assimilation rate upon light and $\mathrm{CO}_{2}$ saturation conditions $\left(\mathrm{A}_{\max }\right)$ of castor bean plants, estimated from $\mathrm{A} / \mathrm{C}_{\mathrm{i}}$ response curves. Each point is the mean of four measurements. Vertical bars indicate the standard deviation of the mean. Asterisks indicate difference by Tukey test at $P \leq 0.05 . \mathrm{WW}=$ well-watered; WS= water-stressed.

Table 1. Effects of water withholding on shoot length, root and shoot dry mass, total chlorophyll concentration, leaf mass per area, total leaf area, root: shoot mass ratio and the leaf area ratio of castor bean plants. WW= well-watered plants; WS= water-stressed plants.

\begin{tabular}{|c|c|c|c|c|c|c|c|c|}
\hline Water status & $\begin{array}{l}\text { Shoot length } \\
(\mathrm{cm})\end{array}$ & $\begin{array}{c}\text { Root biomass } \\
\text { (g) }\end{array}$ & $\begin{array}{c}\text { Shoot biomass } \\
\text { (g) }\end{array}$ & $\begin{array}{l}\text { Chl } \\
\mathrm{g} / \mathrm{m}^{2}\end{array}$ & $\begin{array}{l}\text { LMA } \\
\left(\mathrm{g} . \mathrm{m}^{-2}\right)\end{array}$ & $\begin{array}{l}\text { TLA } \\
\left(\mathrm{m}^{2}\right)\end{array}$ & $\begin{array}{c}\mathrm{R}: \mathrm{S} \\
\left(\mathrm{g} \cdot \mathrm{g}^{-1}\right)\end{array}$ & $\begin{array}{c}\text { LAR } \\
\left(\mathrm{m}^{2} \cdot \mathrm{g}^{-1}\right)\end{array}$ \\
\hline WW & $16,1 \pm 5.1$ & $9.33 \pm 6.3$ & $8.13 \pm 4.5$ & $462 \pm 58.5$ & $45.0 \pm 4.82$ & $768.8 \pm 514$ & $1.69 \pm 2.1$ & $41.4 \pm 19.5$ \\
\hline WS & $3,99 \pm 0.88$ & $1.12 \pm 0.36$ & $1.02 \pm 0.24$ & $555 \pm 84.5$ & $39.1 \pm 4.48$ & $78.59 \pm 24.6$ & $1.10 \pm 0.32$ & $37.9 \pm 12.2$ \\
\hline Tukey test & $*$ & $*$ & $*$ & $*$ & $*$ & $*$ & ns & ns \\
\hline
\end{tabular}

* Values are mean \pm S.D $(\mathrm{n}=20$ for WW and 27 for WS). Asterisks $(*)$ indicate difference at $P \leq 0.05$

\section{Acknowledgements}

The authors thank the Conselho Nacional de Desenvolvimento Científico e Tecnológico $(\mathrm{CNPq})$ for the graduate fellowship awarded to first author and Dr. Lúcia Rebello Dillenburg (PPG-BotânicaUFRGS) for useful comments and suggestions to the manuscript.

\section{References}

Aerts, R. \& Chapin, F.S. 2000. The mineral nutrition of Wild Plants Revisited: A Re-evaluation of Process and Patterns. Advances in Ecological Research 30: 2-55.
Anya, A.O. \& Herzog, H. 2004. Water use efficiency, leaf area and leaf gas exchange of cowpeas under mild-season drought. European Journal of Agronomy 20: 327-339.

Barbour, M.M. \& Buckley, T.H. 2007. The stomatal response to evaporative demand persists at night in Ricinus communis plants with high nocturnal conductance. Plant, Cell and Environment 30: 711-721.

Boyer, J.S.; Chin-Wong, S. \& Farquhar, G.D. 1997. $\mathrm{CO}_{2}$ and water vapour exchange across leaf cuticle (epidermis) at various water potentials. Plant Physiology 114: 185-191.

Buckley, T.N.; Farquhar, G.D. \& Mott, K.A. 1997. Qualitative effects of patchy stomatal conductance distribution features on gas-exchange calculations. Plant, Cell and Environment 20: 867- 880. 
Chaves, M.M. 1991. Effects of water deficits on carbon assimilation. Journal of Experimental Botany 42: 1-16.

Dai, Z.; Edwards, G.E. \& Ku, M.S.B. 1992. Control of photosynthesis and stomatal conductance in Ricinus communis L. (castor bean) by leaf to air vapour pressure deficit. Plant Physiology 99: 1426-1434.

Farquhar, G.D. \& Sharkey, T.D. 1982. Stomatal conductance and photosynthesis. Annual Review of Plant Physiology 33: 317-345.

Flexas, J.; Bota, J.; Escalona, J.M.; Sampol, B. \& Medrano, H. 2002. Effects of drought on photosynthesis in grapevines under field conditions: an evaluation of stomatal and mesophyll limitations. Functional Plant Biology 29: 461-471.

Flexas, J. \& Medrano, H. 2002. Drought-inhibition of photosynthesis in C3 plants: stomatal and non-stomatal limitations revisited. Annals of Botany 89: 183-189.

Geiger, D.R. \& Servaites, J. 1994. Diurnal regulation of photosynthetic carbon metabolism in C3 plants. Annual Review of Plant Physiology and Plant Molecular Biology 86: 159-167.

Giménez, C.; Mitchell, V.J. \& Lawlor, D.W. 1992. Regulation of photosynthesis rate of two hybrids under water stress. Plant Physiology 98: $516-524$.

Gunasekera, D. \& Berkowitz, G.A. 1993. Use transgenic plants with Rubisco antisense to evaluate the rate limitador of photosynthesis under water stress. Plant Physiology 103: 629-635.

Jones, H.G. \& Corlett, J.E. 1992. Current topics in drought physiology. Journal of Agricultural Science 119: 291-296.

Lawlor, D.W. 2002. Limitation to photosynthesis in water-stressed leaves: stomata vs. metabolism and the role of ATP. Annals of Botany 89: 871-885.

Lawlor, D.W. \& Cornic, G. 2002. Photosynthetic carbon assimilation and associated metabolism in relation to water deficits in higher plants. Plant, Cell and Environment 25: 275-294.

Lecoeur, J. ; Wery, J. ; Ture, O. \& Tardieu, F. 1995. Expansion of pea leaves subjected to short water deficit: cell number and cell size are sensitive to stress at different periods of leaf development. Journal of Experimental Botany 46: 1093-1101.

Long, S.P; Humphries, S.\& Falkowski, P.G. 1994. Photoinhibition of Photosynthesis in nature. Annual Review of Plant Physiology and Plant Molecular Biology 45: 633-662.
Marler, T.E. \& Mickelbart, M.V. 1998. Drought, Leaf Gas Exchange, and Chlorophyll Fluorescence of Field-grown Papaya. Journal of American Society of Horticultural Science 123: 714-718.

Medrano, H.; Parry, M.A.; Socias, X. \& Lawlor, D.W. 1997. Long-term water stress inactives Rubisco in subterranean clover. Annals of Applied Biology 131: 491-501.

Osório, M.L.; Breia, E.; Rodrigues, A.; Osório, J.; Le Roux, X.; François, A.D.; Ferreira, I. \& Chaves, M.M. 2006. Limitations to carbon assimilation by mild drought in nectarine trees growing under field conditions. Environmental and Experimental Botany 55: 235-247.

Poorter, H \& Nagel, O. 2000. The role of biomass allocation in the grown response of plants to different levels of light, $\mathrm{CO} 2$, nutrients and water: a quantitative review. Australian Journal of Plant Physiology 27: 595-607.

Qaderi, M.R., Kurepin, L.V., Redi, D.M. 2006. Growth and physiological responses of canola (Brassica napus) to three components of global climate change: temperature, carbon dioxide and drought. Physiologia Plantarum 128: 710-721.

Romero, P. \& Botía, P. 2006. Daily and seasonal patterns of leaf water relations and gas exchange of regulated deficit-irrigated almond tress under semiarid conditions. Environmental and Experimental Botany 56: $158-173$.

Schurr, U.; Heckenberger, U.; Herdel, K.; Walter, A. \& Feil, R. 2000. Leaf development in Ricinus communis during drought stress: dynamics of growth process, of cellular structure and of sink-source transition. Journal of Experimental Botany 51: 1515-1529.

Tezara, W.; Mitchell, V.J.; Driscoll, S.D. \& Lawlor, D.W. 1999. Water stress inhibits plant photosynthesis by decreasing coupling factor and ATP. Nature 401: 914-917.

von Caemmerer, S. \& Farquhar, G.D. 1981. Some relationships between the biochemistry of photosynthesis and the gas exchange of leaves. Planta 153: 376-387.

Wintermans, J.F.G.M. \& De Mots, A. 1965. Spectrophotometric characteristics of chlorophylls a and $\mathrm{b}$ and their pheophytins in ethanol. Biochimica et Biophysica Acta 109: 448-453. 